\title{
Analysis of Competitive Advantage in the perspective of Resources Based View.
}

\author{
Toni Herlambang ${ }^{1}$, Eka Afnan. $T^{2}$, Achmad Sudiro ${ }^{3}$, Noermijati ${ }^{4}$ \\ ${ }^{I}$ (Department of Management Science, University of Brawijaya, Indonesia) \\ ${ }^{2}$ (Department of Management Science, University of Brawijaya, Indonesia) \\ ${ }^{3}$ (Department of Management Science, University of Brawijaya, Indonesia) \\ ${ }^{4}$ (Department of Management Science, University of Brawijaya, Indonesia)
}

\begin{abstract}
Conditions of competition between colleges service providers, both private and state, require leaders and college administrators to do everything possible in order to gain competitive advantage compared with other similar institutions. In the perspective of RBV attempt to gain competitive advantage through the utilization of internal resources of the organization consisting of tangible aspects, intangible aspects, as well as the capability aspects. So far, in the research of Competitive Advantage on RBV perspective, in the context of universities has not existed yet that combine the aspects of tangible, intangible, and capability in a research model to study.

This study aims to analyze the effect of market orientation, HR Competencies and Territory Management in creating a competitive advantage, as well as its impact on organizational performance. The survey research is conducted at 142 Institutions of Higher Education of Muhammadiyah in Indonesia, represented by the head of each institutions.

The research findings indicate that Competitive Advantage is significantly influenced by market orientation and HR (Human Resources) Competence. Meanwhile, HR Competency directly no significant effect on organization performance, but must be mediated by a Competitive Advantage. Meanwhile, the Territory Management can directly affect the performance of organizations, but has no effect on Competitive Advantage.

Keywords - Competitive Advantage, Human Resources Competencies, Market Orientation, Organizational Performance, Territory Management.
\end{abstract}

\subsection{Research background}

\section{INTRODUCTION}

Competition for students among universities is unavoidable due to the rapidly growing number of colleges so that every higher education must equip themselves in order to survive in the competition which in turn, colleges that are not sensitive to the competition situation will be less progressed and closed [1]. Competition is described as a cyclical company that is determined by the four components of the competition (4C), those are, company, customers, competitors, and change[2]. For higher education providers, customers who directly enjoy the services they offer are students. Meanwhile, the competition is a kind of education providers of the same level, and the change includes any change in the internal and external pressures initiatives, both academic and non-academic.

To win the competition of today's business, enterprises should have a good strategy. There are many opinions about the strategy, one of which is the opinion of Johnson and Scholes [3] which says that,: "Strategy is the direction and scope of an organization over the long term: which achieves advantage for the organisation through its configuration of resources within a challenging environment, to meet the needs of markets and to fulfil stakeholder expectations". Companies that implement strategies quickly and accurately is a company that has a competitive advantage to win the competition, as proposed by Thompson and Strickland [4] that: "A business strategy is powerful if it produces a sizable and sustainable competitive advantage; it is weak if it results in competitive disanvantage". In the context of competition between universities, aspects of Competitive Advantage becomes absolutely necessary to ensure continuity of operations and the achievement of the organization's long-term goals.

\section{Aspects of the Competitive Advantage}

Talking about the Competitive Advantage, Porter [5] in his theory called Porter's five-forces model of analyzing the threats and opportunities in the industry. Introduced the concept of Porter's Competitive Advantage has received criticism from various parties, including Teece [6] and Barney [7]. They criticize that Porter's model only shows the profitability of the industry and not the individual company. Porter's five-forces model is not much help companies to identify and maintain a unique and sustainable advantages. From the criticism are then developed the concept of Competitive Advantage is more focused on the resources and 
capabilities, which is also called the Resource Based View (RBV). The statement of Hitt et al.,[8]: "Resourcebased view is based on the idea that 1) firm's resources, capabilities, and competencies facilitate the development of sustainable competitive advantage, and 2) competitive advantages are achieved when the strategies are successful in leveraging these resources ". RBV emphasizes that competitive advantage based on resources and capabilities is more sustainable than those based on product / market positioning. The resources owned by the company include financial, physical, human, intangible assets and structural-cultural assets.

Resources-based Theory of the Firm (RBT) in the conception of strategic management emphasis on the importance of firm resources and capabilities that if managed properly will result in the ability to generate returns above the level of normal [9][10][11][12][13]. According to the RBT, one way to produce a sustainable competitive advantage is to develop a kind of specificity typical of resources and capabilities of the company the firm's specific resources (FSR), and therefore difficult to replicate.

RBV concept of the Competitive Advantage believes that internal resource is more important for the Institute of Higher Education rather than external factors in order to achieve and maintain excellence in competition among higher education providers. So it can be explained logically, that the Higher Education Organizational Performance will be achieved if the operationalization of internal resources has specific advantages over competitors college.

Barney [14][15] defines the resource companies to incorporate elements of capability and organizational processes as the resources controlled by the company to enable the company to improve the quality strategy. Based on this definition, in the context of strategic research resources associated with the condition in a university to achieve the expected performance of the organization, still little research found that by combining elements of market orientation, competency of human resources, and territory management in an empirical study to reveal representative overview and analysis of the relationships that make up the competitive advantage in the RBV perspective on Higher Education.

\section{Aspects of the Market Orientation}

Based on literature studies, indicated that most of the research on the implementation of market orientation conducted at for-profit organization engaged in manufacturing. Cervera, et al., [16] noted that a number of similar studies in non-profit organizations, including educational organizations particularly universities has been relatively little. In fact, according to Kotler and Levy [17] that market orientation is the implementation of marketing concepts relevant to all types of organizations that deal with customers and other interested parties. This phenomenal opinion has been widely used by researchers as a basis for implementing the marketing concept in a variety of organizations (including hospitals, museums and universities) in order to offer products and services to suit the needs of their customers [18]. Another factor that may be incentive for universities to adopt a market orientation is globalization. The era of the free market has causing the emergence of foreign higher education organization that is ready to compete with domestic universities. According to the marketing concept, an organization can survive and win the competition in the global market is an organization that is able to offer more value and in accordance with the wishes of the customer[19]. This suggests that the free competition today, college is supposed to design a market-oriented activities[20]. Opinions by the marketing experts, the basis for the use of a market orientation as one of the variables in this study.

\section{Aspects of the HR Competency}

On the other hand, as the support of Competitive Advantage in the RBV perspective, Wright et al., [21] suggested the importance of human resource capabilities in achieving competitive advantage. Capabilities of the personnel act as a collective knowledge of members of the company (hard to duplicate), which was developed in a certain period of time (rare), and are valuable for the company to manage its employees routine will direct all employee attitudes and talent in the formation of values and achieve a purpose so that competitive advantage is achieved. Lengnick and Lengnick-Hall[22], stated that the combination of the capabilities of the personnel, resources and quality decision will allow the company to capitalize on the opportunities available in the market as well as minimizing the risk / threat. The same opinion was delivered Brewster et al., [23] who argued that in order to obtain a strong competitive advantage and survive in the long term, the company should have an edge in skill and capability that is owned by its employees. Based on expert opinion about the competency of human resources, the basis for the use of HR Competency as a Competitive Advantage Variable support in this study.

\section{Aspects of the Territory Management}

Furthermore some researchers have also proposed Territory Management to support aspects of Competitive Advantage. Burgoyne et al., [24] suggested that, overall, two-thirds (approximately 67\%) managed the marketing area in general has a chance to develop if management can manage and develop a territory management practices well. This opinion is supported by a freelance writing published on the Agency Sales 
Magazine [25], noted the importance of the role of territory management to help the company improve sales and excellence of the company.

Territory management success is strongly influenced by the ability of the manager to see the sales potential of a region. Allen [26] present a variety of ways that a territory management practices can be an advantage for the company to compete with its competitors, which build confidence, learn what customers want, ask questions that can extract the information and the salesperson should be more frequent listening than talking In this study aspects of Territory Management is also used as auxiliary variables of Competitive Advantage.

\subsection{Research Gap}

The main consideration is the background of this study, from a review of the existing empirical research findings illustrate the contradiction, the underlying concept of the relationship between variables, namely, research on market orientation with various backgrounds in general successfully proved that the market orientation will improve marketing performance [27][28][29]. however, some studies did not succeed to prove that the market orientation can improve marketing performance [30][31][32][33][34]. Therefore in this study will incorporate Competitive Advantage variable, as variable between Market Orientation of relations, HR Competencies, and Territory Management on Organizational Performance. Based on the "Research Gap" between the work of many researchers, especially in the context of inter-university competition, a rational reason for this study was conducted to fill the research gap and determine the extent of competitive advantage for organizations achieve performance, which has been conducted by the Higher Education of Muhammadiyah (PTM) in Indonesia through the implementation of Territory Management, HR competencies, and Market Orientation.

\subsection{Research Problem}

Departing from the principle of Strategic Management in the literature, that to gain competitive advantage, in the perspective of Resource Based View (RBV) need action and strategic decisions on resource key factors, which by Barney [35] categorized the tangible elements, intangible, and Capability. The resource section is used as a key factor of this study is variable Territory management, HR Competencies, and the extent of market orientation can establish a competitive advantage in order to achieve organizational performance of PTM in Indonesia, so the specific formulation of the problem in this study is :" How to develop a Competitive Advantage through Market Orientation, HR Competencies, and Territory Management, against Organizational Performance and how to give an explanation of the differences in the results of research on the relationship of market orientation, HR Competencies, Territory Management as a Competitive Advantage formers to create organizational performance in the context of Higher Education?".

\subsection{Originality of Research}

Differences in this study with previous research, is in general research on competitive advantage in the RBV perspective on key aspects of resource resource to study only view of the criteria only tangible, intangible, or capability alone, not comprehensively, so often unable to explain how the accumulation internal resources as determining factors of competitive advantage can improve organizational performance. Originality empirical research model in this study starts from the factors that can affect competitive advantage, through the intangible aspects of the variable measuring the market orientation, the aspect of capability through human resource competency measurement, and tangible aspects the measure of terittory management, so as to obtain clarity on how to improve excellence competitive in a college organization in order to improve performance. In contrast to previous studies, which generally emphasizes the causal relationship between the performance of the organization's competitive advantage, so research which test on antecedent competitive advantage in the RBV perspective on Non Profit Organization Oriented still very limited.

\subsection{Research Objectives and Benefits}

The purpose of this study was to analyze the influence of market orientation, HR Competencies, Territory Management against competitive advantage, as well as its association with organizational performance on The Higher Education of Muhammadiyah in Indonesia. The benefits of research is conceptually Contribute to the development of competitive advantage research models based RBV approach through tangible aspects of resources, intangible resources, and capability, in particular the perspective of market orientation, competence of human resources, and territory management in the field of Strategic Management in general, and specifically on Competitive Advantage variation study in Higher Education Organizational Objects. 


\subsection{Litle Story of RBV}

\section{Concept Framework and Research Model}

Theory of Resources-Based View (RBV) as a basis for gaining competitive advantage of a firm lies primarily in the application bundle valuable internal resources in the form of tangible, intangible, and capability in every activity of the company [36][37][38]. The birth of the concept of RBV starting from Penrose opinion, [39][40][41] which states:" a collection of productive resources the disposal of which between different uses and over time is determined by administrative decision"'[42]. In order to appreciate significantly from the theory of Penrose, Wernerfelt [43] began to introduce the terminology of "RBV", Warnerfelt argued that existing obstacles to internal resource constraints analogous to levels comparable with externally Industry. Companies can create some sort of advantage or differentiator that much more effectively through the exploitation of its resources positions excellence. the concept is in stark contrast to the concept of Industrial Organization (IO), which stated that the economic performance of the company depends on how well the company's position in the industry [44][45].

By focusing on the company's internal resources is more than just a production function [46], it is certain that the Competitive Advantage can be produced through strict controls to create a "scarcity" and resources are difficult to imitate. [47][48][49]. Another argument states that if two companies have similar resources, then it can not be stated that the available resources are identical. Because in reality no two companies are the same and identical managed in the long term and the management of almost all companies use approaches adjusted to the characteristics of the available resources of each [50].

A number of research, development, and improvement in thought stimulation by Wernerfelt [51] has been widely produced [52][53][54][55]. In summary, Barney [56] found, that if the company can pursue extensively difference of managed resources, will be able to increase the value of companies in the industry. This will make the company thrive in the industry heterogeneity. Dierickx and Cool [57], on the other hand suggest that it is very difficult for a company to replicate the resource belongs to its competitors, because technically the time used and adjustments are made to be inefficient and limited opportunities to use resources results in a change in the business scene. In his paper, Barney [58] provides guidance for the thinkers to give attention to the attributes of resources to get a Competitive Advantage[59][60]. He suggested that high performance can be achieved, then the internal resource management is necessary aspects of Value, rareness, Inimitability, or without being able to be replaced with other strategic resources in the operational resources [61]. The four attributes associated with the performance characteristics of the company's internal.

\subsection{Variables forming Competitive Advantage}

In order to understand how to set this competency can improve competitive advantage of the company, the concept of organizational capital or capabilities [62][63] used in this study. Barney [64] proposed three types of advantages Typical companies that can generate rents for the company, namely: (1) physical capital, (2) human capital, and (3) organizational capital. One of the "invisible assets" that can arise from this category is the portfolio of organizational capability (eg the Market Orientation systems, control systems and coordination in the management of Regional Marketing, informal relationships, system level of organization in the HR Competency) were seeded, developed and polished from day to day in the organization, so that it is inherent in organizational processes, which can be socially complex, sometimes difficult to identify and therefore difficult to imitate [65][66][67], because it can also seen as part of the social capital inherent in the company.

Organizational capabilities can be defined as the competence or the ability to work effectively in tasks and specific purposes including the ability to transfer knowledge and skills to new tasks and situations as well as the motivation to strengthen the capacity and capability resulting from a set of relevant attributes such as knowledge, abilities, skills, attitudes are evolving and embedded within the organization [68][69][70]. In other words, organizational capabilities can be viewed as a socially complex set of 'doing things' [71][72][73][74] which is essentially difficult to imitate by competitors. An organization must exploit existing business opportunities by using available resources while generating and developing a new set of resources to maintain competitiveness in the future market environment, then, the organization must be involved in the management and development of resources [75][76]. Their writings explain that to maintain a competitive advantage, it is important to develop resources that will strengthen the company's ability to continue its superior performance. Any industry or market reflects high uncertainty and to survive in the competition, specifically the development of new resources becomes very necessary. Morgan et al., [77], stating that the need to update the resource management is a major task for all of the business environment and market environment reflecting conditions are very unpredictable [78].

\section{3 filing of Model}

Taking the basis of the concept of tangible, intangible, and capability in key internal resources in each activity firms [79][80][81]. The research model developed using the basic theory of competitive advantage 
perspective of RBV [82]. Tangible aspects of this research are discussed in the management of variable region or in the context of competition called the Territory management services [83], Aspects of Capability examined in this study of human resource competence variable [84]. Intangible aspects discussed in this study of variable market orientation [85]. Based on the concept and previous research findings as a reference, this study develops the concept of Competitive Advantage in the perspective of Resources Based View, which will conduct the analysis and conduct a comprehensive study Effect of Market Orientation, HR Competencies, and Territory Management for Competitive Advantage in order to realize Organizational Performance in The Higher Education Muhammadiyah in Indonesia. On the basis of a sustainable Competitive Advantage models of Fahy, [86] and an explanation of the conceptual framework of the relationship between variables forming Competitive Advantage organizations to achieve performance that includes Variable Market Orientation, HR Competencies, and territory management, it can be constructed Hypothesis model in Figure 1. as follows:

\section{submission of hypothesis}

Mazaira et al., [87] noted the importance of the role of market orientation in building a company's competitive advantage. If the company has a corporate marketing strategy that is different from its competitors, the company will gain a competitive advantage. Market orientation focuses on the hard efforts to always create customer satisfaction that is expected to bring a positive impact on the profitability of the company. Slater and Narver [88] suggested that market orientation is: a culture that puts a high priority on every creation and maintenance of superior customer value with due regard to the interests of stakeholders so that excellence can be achieved and provide behavioral norms regarding development and response to market information. Narver et al., [89] suggested that the core of market orientation is the commitment of all members of the organization to always create added value from consumers. Based on the literature review the relationship of market orientation and competitive advantage, can be made a model of the following hypothesis:

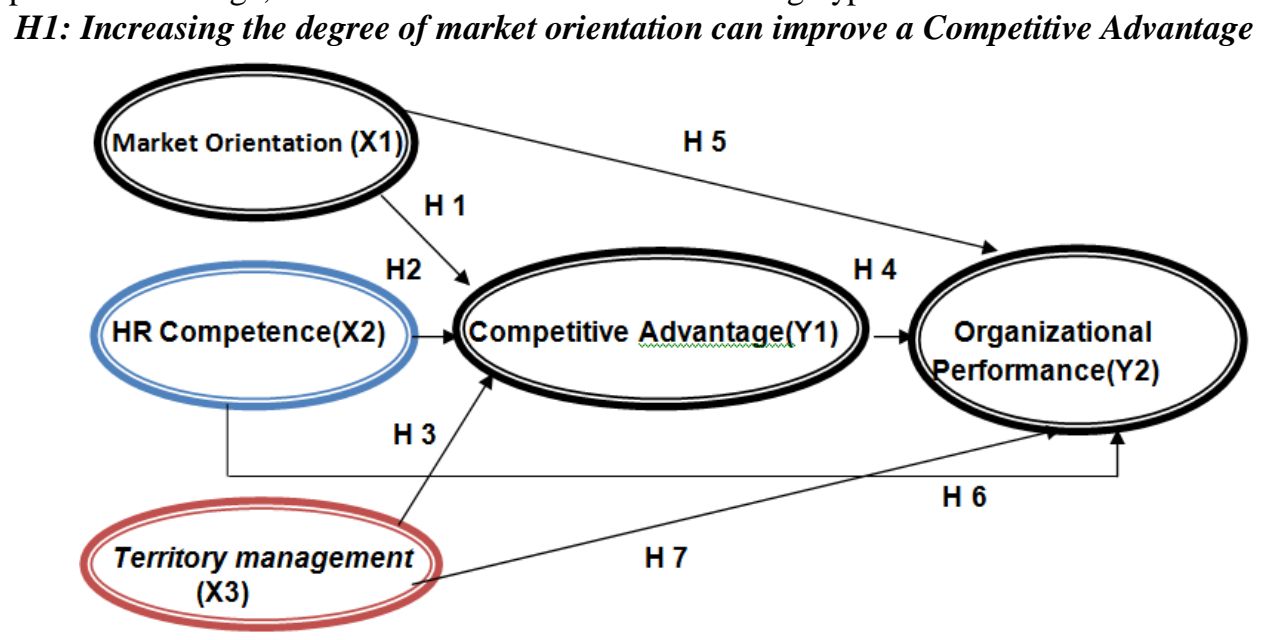

Figure 1. Hypothesis Model

Some researchers have realized the importance of human resource competencies, capabilities and skills as the main source of competitive advantage of the company [90][91]. In his writings, Wright et al., [92] suggested the importance of human resource capabilities as a collective knowledge of members of the company (hard to duplicate), which was developed within a certain period of time (rare), and are valuable for routine company in managing its employees will direct all employee attitudes and talent in the formation of values and achieve a goal that will be achieved competitive advantage. Brewster et al., [93] suggested that in order to obtain a strong competitive advantage and survive in the long term, the company should have an edge in skill and capability that is owned by its employees. Based on the literature review relations HR competencies and competitive advantage, can be made a model of the following hypothesis:

\section{H2: Increased HR Competency degrees can improve a Competitive Advantage}

Territory management itself is a continuous process and occurs feedback and redesign the event of changes in customer and market. Burgoyne et al., [94] suggests that there is no theory of Territory Management practices. Territory Management Quality varies widely, depending on the marketing of the entire region into other marketing areas, but as a whole, two of the three areas of marketing in general has the opportunity to grow, and if it can be managed and developed well Territory Management can be a source of competitive advantage for firms. Based on the territory management literature review relationship with a competitive advantage, can be made a model of the following hypothesis: 


\section{H3: Increasing the degree of implementation of the territory management can improve competitive advantage.}

Strandskov [95] measures the company's competitive advantage by using four variables, namely Firm Specific Advantages, Advantages Specific Localization, Relationship Specific Advantages and Competitive Strenghts / Performance. The results He found that competitive advantage in the form of Firm Specific Advantages and Relationship Specific Advantages over effect on the success of the business performance. Based on the literature review the relationship of competitive advantage and organizational performance, can be made a model of the following hypothesis:

\section{H4: Increasing the degree of competitive advantage can improve the performance of the} organization.

Baker \& Sinkula study [96] shows that market orientation is significantly related to company performance. Meanwhile, Han et al., [97] state that market orientation but not significant positive effect on firm performance. However, in these studies revealed that the significant effect of market orientation on company performance, through innovation as an intervening variable. Based on the research [98][99] which says positive influence between market orientation and company performance, then proposed the following hypothesis:

H5: Increasing the degree of market orientation can improve the performance of the organization.

Empirical evidence is found in a number of leading business organizations in the world shows that the growth and competitive-owned power generated through specific competencies that are created through the development of high skills for employees, the uniqueness of the organization's culture, systems and process management. Weatherly, [100] found that approximately 85 percent of the company's market value (performance) is determined by the Human Resources. Studies focus related to the implementation of human resources management strategy that is right for the organization is still dominated by the fit strategic approach. This approach was widely criticized in the literature of human resource management, especially since tight fit with the organizational strategy of HRM practices considered to limit the possibility of innovation and creative space for HR practices [101]. But differences of opinion is still not reduce the confidence of writers and researchers that there is a direct link HR strategy to organizational performance management. In fact there is some consensus that high performance will only be obtained by organizations that pay attention to adopt HRM policies specifically related to the organization's strategy [102]. Approach fit in strategy research-based human resource management on organizational fit theory, [103][104]. This theory explains that the organization's performance is largely determined by the degree of conformity or consistency relations in the management of an organization's internal variables, one of which is human resource management practices. Results of the survey on manufacturing firms in the United States proves that High Performance Work Systems index correlated with HRM systems. HR performance is highly correlated with the performance of the company and called the system of human resource management practices in the organization [105] [106] [107], then put forward the following hypothesis:

\section{H6: Increased HR Competency degree can improve the performance of organizations}

Because the company is basically seen as a "going concern", which exist and grow not only for the sake of right, but the long-term sustainability or that by Seth and Thomas [108] articulated as "to maintain longterm viability", then the question that arises is how the long-term continuity can be established and maintained? One answer can be obtained through the concept of social capital in the order of resource-based theory of the firm, stating that the company's long-term existence and variety of strategic progress depends on the degree of social capital investment is done in an environment in which it operates in the context of a competition called the Territory management.

Many studies have been done on the social constructs in management to gain competitive advantage, marketing performance, and Organizational Performance [109] [110] [111] [112] [113] [114] [115] which put the study conception of social capital into one of the key factors in generating performance. However, the question that still remains is the question of how the completeness of resource and social capabilities in the resource-based theory, including the views of Oliver [116] that the resource-based theory in particular has not tested a variety of social contexts commonly considered in the selection of resources and the development as a strategic resource as social traditions, social networking is built in the context of marketing areas, pressures regulatory environment in which it operates, and how these contextual matters could have an impact on sustainable competitive advantage. then from the study of the elements Territory Management to Organizational Performance, proposed the hypothesis as follows:

H7: Increased degree of Quality Territory management can improve the performance of the organization

Approach and type of Research

The approach used in this study is a quantitative approach (positivism). Quantitative research is an approach that works with numbers, numbers tangible data, analyzed using statistics to answer the question or test a specific hypothesis and to predict that a particular variable affects another variable [117]. Quantitative 
approach based on principles of rational empirical studies so that before doing the study the researchers have provided problems and hypotheses to be tested based on the specified criteria and analytical tools used. Type of research is explanatory research, the research conducted for the purpose of explaining (explanatory) relationships between variables through hypothesis testing.

\section{Population and Research Sample}

Based on the characteristics of the data analysis needs, the unit of analysis in this study is the organization of Higher Education Muhammadiyah (PTM) in Indonesia. So the target population in this study are all Institutions of Higher Education Muhammadiyah in Indonesia, where each PTM represented by leaders (Rector / Director / Chairman) respectively. This research takes an entire population His study program has been accredited by BAN PT (national accreditation body) number 155 PTM as respondents. So called research with samples saturated, then every institution represented by one respondent on the leadership level. Of the total 155 PTM with the distribution of the study sample consisted of: 40 universities, 76 high schools, 23 colleges, 4 technical colleges, and 14 universities of Religion. The instrument used to collect data in this study is a questionnaire that a list of written questions, where respondents were asked to answer or fill out a few things regarding the identity (name, age, occupation, status Occupation, and long into university leader) and give response to the level of the indicators of the suitability of the study variables on objective reality in the PTM, as perceived by the respondents.

\begin{tabular}{|l|l|l|c|c|c|}
\hline NO & \multicolumn{1}{|c|}{ TYPE } & \multicolumn{1}{c|}{ LEADERS } & DISTRIBUTION & RETURN & $\%$ \\
\hline 1. & University & Rector & 40 & 30 & $75 \%$ \\
\hline 2. & Polytechnic & Director & 04 & 02 & $50 \%$ \\
\hline 3. & High School & Chairman & 76 & 75 & $98 \%$ \\
\hline 4. & Academy & Director & 23 & 22 & $95 \%$ \\
\hline 5. & Relegion HS & Chairman & 14 & 13 & $93 \%$ \\
\hline \multicolumn{2}{|c|}{ Questionnaires TOTAL } & 155 & 142 & $91 \%$ \\
\hline
\end{tabular}

Table 1. Sample Distribution and Research Questionnaire

Questionnaires conducted through Express Mail service was recorded, after first obtaining permission in PTM perform data collection in Indonesia by the Leadership Council of Higher Education, Central Executive of Muhammadiyah in Yogyakarta. Because according to the rules Persyarikatan Muhammadiyah, the top leadership in Muhammadiyah universities should be responsible for the Council of Higher Education PP.Muhammadiyah. In order to maximize the return of questionnaires, intensive research call by phone the contact person from each of the institutions of Higher Education for the right target. Period of deployment and return of the questionnaire, conducted in July 2012 until October 2012.

Out of 155 questionnaires distributed, 13 of them did not return, researchers have been tried to call back from universities that do not send back the questionnaire, it turns out some of them have stated to send via e-mail, but after a researcher checks are not there. So that there are only 142 questionnaires were feasible for use in data analysis. Total sample of 142 people is still considered adequate for SEM analysis [118].

\section{Market Orientation Variables}

\section{Results and Discussion}

Variables defined market orientation as an organizational culture that most effectively and efficiently to bring the behaviors necessary to create a "superior value" for service users in Muhammadiyah universities and produce "superior performance" for college organization Muhammadiyah, presented three main indicators of The variables of market orientation is customer orientation, competitor orientation, and Coordination between intra and functions inside organizations of Muhammadiyah universities. 
Analysis of Competitive Advantage in the perspective of Resources Based View.

Table 2. Description of Market Orientation Variables (X1)

\begin{tabular}{|c|c|c|c|c|c|c|c|}
\hline \multirow{2}{*}{$\begin{array}{l}\text { indicator } \\
\text { Variables }\end{array}$} & \multirow{2}{*}{ Item } & \multicolumn{5}{|c|}{ Answer Percentage of Respondents (\%) } & \multirow[t]{2}{*}{ (Mean) } \\
\hline & & 1. & 2. & 3. & 4. & 5. & \\
\hline \multirow{4}{*}{$\begin{array}{l}\text { Customer } \\
\text { Orientation } \\
\text { (X1.1) }\end{array}$} & $\mathrm{X} 1.1 .1$ & 0 & 6,3 & 30,3 & 62,7 & 0,7 & 3,58 \\
\hline & $\mathrm{X} 1.1 .2$ & 0 & 6,3 & 26,1 & 67,6 & 0 & 3,61 \\
\hline & $\mathrm{X} 1.1 .3$ & 0 & 9,2 & 49,3 & 41,5 & 0 & 3,32 \\
\hline & \multicolumn{6}{|c|}{ Mean Customer Orientation Indicator (X1.1) } & 3,50 \\
\hline \multirow{4}{*}{$\begin{array}{l}\text { Competitor } \\
\text { orientation } \\
(X 1.2)\end{array}$} & $\mathrm{X} 1.2 .1$ & 0 & 11,3 & 51,4 & 35,9 & 1,4 & 3,27 \\
\hline & $\mathrm{X} 1.2 .2$ & 0,7 & 12,0 & 47,9 & 38,7 & 0,7 & 3,27 \\
\hline & $\mathrm{X} 1.2 .3$ & 0,7 & 2,8 & 37,3 & 58,5 & 0,7 & 3,56 \\
\hline & \multicolumn{6}{|c|}{ Mean Competitor Orientation Indicator (X1.2) } & 3,37 \\
\hline \multirow{4}{*}{$\begin{array}{l}\text { Coordination } \\
\text { between } \\
\text { intra } \\
\text { functions } \\
P T M(X 1.3)\end{array}$} & $\mathrm{X} 1.3 .1$ & 0 & 2,8 & 64,8 & 29,6 & 2,8 & 3,32 \\
\hline & $\mathrm{X} 1.3 .2$ & 0 & 2,1 & 58,5 & 38,0 & 1,4 & 3,39 \\
\hline & $\mathrm{X} 1.3 .3$ & 0 & 0,7 & 62,0 & 35,2 & 2,1 & 3,39 \\
\hline & \multicolumn{6}{|c|}{ Mean Coordination between functions (X.1.3) } & 3,37 \\
\hline \multicolumn{7}{|c|}{ Variable Mean Market Orientation (X1) } & 3,41 \\
\hline
\end{tabular}

Table 3 Loading Factor ( $\lambda$ ) Measurement of Market Orientation Variables (X1)

\section{Variable HR Competency}

HR Competency variable (X2) is a personal ability to perform his job in order to get results, with human resource competency indicators as basic characteristics consisting of the ability (skill), knowledge (knowledge), and personal attributes (personal attributs).

\begin{tabular}{|c|c|c|c|c|c|c|c|}
\hline \multirow{2}{*}{$\begin{array}{l}\text { Indicator } \\
\text { Variables }\end{array}$} & \multirow[t]{2}{*}{ Item } & \multicolumn{5}{|c|}{ Answer Percentage of Respondents (\%) } & \multirow[t]{2}{*}{ 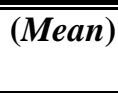 } \\
\hline & & 1. & 2. & 3. & 4. & 5. & \\
\hline \multirow{4}{*}{$\begin{array}{l}\text { HR Ability } \\
(\text { skill })(X 2.1)\end{array}$} & $\mathrm{X} 2.1 .1$ & 0,7 & 6,3 & 51,4 & 41,5 & 0 & 3,34 \\
\hline & $\mathrm{X} 2.1 .2$ & 0 & 2,8 & 30,3 & 66,9 & 0 & 3,64 \\
\hline & $\mathrm{X} 2.1 .3$ & 0 & 7,7 & 44,4 & 47,9 & 0 & 3,40 \\
\hline & \multicolumn{6}{|c|}{ The mean indicator ability (skill) (X2.1) } & 3,46 \\
\hline \multirow{4}{*}{$\begin{array}{l}\text { Knowledge } \\
\text { (knowledge), } \\
(X 2.2)\end{array}$} & $\mathrm{X} 2.2 .1$ & 0 & 1,4 & 55,6 & 40,8 & 2,1 & 3,44 \\
\hline & $\mathrm{X} 2.2 .2$ & 0 & 0,7 & 72,5 & 24,6 & 2,1 & 3,28 \\
\hline & $\mathrm{X} 2.2 .3$ & 0 & 0 & 59,9 & 36,6 & 3,5 & 3,44 \\
\hline & \multicolumn{6}{|c|}{ Indicators Mean Knowledge (knowledge) (X2.2) } & $\mathbf{3 , 3 8}$ \\
\hline \multirow{5}{*}{$\begin{array}{l}\text { personal } \\
\text { attributes } \\
\text { (personal } \\
\text { attributs).(X2.3) }\end{array}$} & $\mathrm{X} 2.3 .1$ & 0 & 0,7 & 40,8 & 57,7 & 0,7 & 3,58 \\
\hline & $\mathrm{X} 2.3 .2$ & 0 & 4,2 & 54,2 & 38,0 & 3,5 & 3,41 \\
\hline & $\mathrm{X} 2.3 .3$ & 0 & 0,7 & 58,5 & 33,8 & 7,0 & 3,47 \\
\hline & $\mathrm{X} 2.3 .4$ & 0 & 0,7 & 57,0 & 38,0 & 4,2 & 3,46 \\
\hline & \multicolumn{6}{|c|}{ Personal Attributes Indicators Mean (X.2.3) } & 3,48 \\
\hline \multicolumn{7}{|c|}{ Variable Mean HR Competency (X2) } & 3,44 \\
\hline
\end{tabular}

Table 4. Description Variable HR Competence (X2)

\begin{tabular}{|c|c|c|c|c|}
\hline \hline \multicolumn{2}{|c|}{ Indicator and Variable } & Mean & Loading Factor \\
\hline $\begin{array}{c}\text { X13 Coordination between intra } \\
\text { functions in PTM }\end{array}$ & $<---$ & X1 Market Orientation & $\mathbf{3 , 3 7}$ & $\mathbf{0 . 7 5 4}$ \\
\hline X12 Competitor orientation & $<---$ & X1 Market Orientation & $\mathbf{3 , 3 7}$ & $\mathbf{0 . 8 5 1}$ \\
\hline X11 Customer Orientation & $<---$ & X1 Market Orientation & $\mathbf{3 , 5 0}$ & $\mathbf{0 . 6 9 3}$ \\
\hline \hline
\end{tabular}

Table 5. Factors loading ( $\lambda$ ) HR Competency Measurement Variables (X2)

\begin{tabular}{|c|c|c|c|c|}
\hline \multicolumn{3}{|c|}{ Indicators and Variables } & Mean & Loading Factor \\
\hline X23 PersonalAttributes & $<--$ & X2 HR Competency & 3,48 & 0.604 \\
\hline X22 Knowledge & $<--$ & X2 HR Competency & 3,38 & 0.773 \\
\hline X21 Ability (skill) & $<---$ & X2 HR Competency & 3,46 & 0.588 \\
\hline
\end{tabular}

The Variable of Territory Management 
Territory Management (X3), has a meaning as a way of managing and directing all PTM customer data and marketing network of distribution area into a fully integrated unit. Indicator of Territory Management is the equal distribution of PTM services products, availability and visibility product, distribution channel activation

\begin{tabular}{|c|c|c|c|c|c|c|c|}
\hline \multirow{2}{*}{$\begin{array}{l}\text { Indicator } \\
\text { Variables }\end{array}$} & \multirow[t]{2}{*}{ Item } & \multicolumn{5}{|c|}{ Answer Percentage of Respondents (\%) } & \multirow{2}{*}{$\begin{array}{l}\text { Rerata } \\
\text { (Mean }\end{array}$} \\
\hline & & 1. & 2. & 3. & 4. & 5. & \\
\hline \multirow{5}{*}{$\begin{array}{l}\text { Equitable } \\
\text { distribution of } \\
\text { PTM products } \\
\text { (X3.1) }\end{array}$} & $\mathrm{X} 3.1 .1$ & 0 & 0 & 60,6 & 32,4 & 7,0 & 3,46 \\
\hline & $\mathrm{X} 3.1 .2$ & 0 & 0 & 64,8 & 31,0 & 4,2 & 3,39 \\
\hline & $\mathrm{X} 3.1 .3$ & 0 & 0,7 & 52,1 & 46,5 & 0,7 & 3,40 \\
\hline & $\mathrm{X} 3.1 .4$ & 0 & 1,4 & 62,7 & 35,2 & 0,7 & 3,35 \\
\hline & \multicolumn{6}{|c|}{ Equity Indicators Mean PTM Products (X3.1) } & 3,42 \\
\hline \multirow{4}{*}{$\begin{array}{l}\text { Availability \& } \\
\text { visibility product } \\
(X 3.2)\end{array}$} & $\mathrm{X} 3.2 .1$ & 0 & 0,7 & 25,4 & 45,1 & 28,9 & 4,02 \\
\hline & $\mathrm{X} 3.2 .2$ & 0 & 0,7 & 26,8 & 42,3 & 30,3 & 4,02 \\
\hline & $\mathrm{X} 3.2 .3$ & 0 & 1,4 & 16,2 & 44,4 & 38,0 & 4,19 \\
\hline & \multicolumn{6}{|c|}{ Indicators Mean Availability \& visibility (X3.2) } & 4,07 \\
\hline \multirow{5}{*}{$\begin{array}{l}\text { Distribution } \\
\text { channel } \\
\text { activation } \\
\text { (X3.3) }\end{array}$} & $\mathrm{X} 3.3 .1$ & 0 & 0 & 13,4 & 52,1 & 34,5 & 4,21 \\
\hline & $\mathrm{X} 3.3 .2$ & 0 & 2,1 & 5,6 & 45,1 & 47,2 & 4,37 \\
\hline & $\mathrm{X} 3.3 .3$ & 0 & 2,1 & 14,1 & 47,2 & 36,6 & 4,18 \\
\hline & $\mathrm{X} 3.3 .4$ & 0 & 2,1 & 6,3 & 56,3 & 35,2 & 4,25 \\
\hline & \multicolumn{6}{|c|}{ Mean Distribution Channel Activation Indicator (X3.3) } & 4,25 \\
\hline \multirow{5}{*}{$\begin{array}{l}\text { Equitable } \\
\text { distribution of } \\
\text { facilities and } \\
\text { infrastructure } \\
\text { promotion }(X 3.4)\end{array}$} & X3.4.1 & 0 & 12,7 & 19,7 & 63,4 & 4,2 & 3,59 \\
\hline & $\mathrm{X} 3.4 .2$ & 1,4 & 12,7 & 24,6 & 57,0 & 4,2 & 3,50 \\
\hline & $\mathrm{X} 3.4 .3$ & 2,8 & 19,7 & 37,3 & 35,9 & 4,2 & 3,19 \\
\hline & X3.4.4 & 2,1 & 13,4 & 38,0 & 38,7 & 7,7 & 3,37 \\
\hline & \multicolumn{6}{|c|}{ The mean equity indicators infrastructure promotion (X3.4) } & 3,41 \\
\hline \multicolumn{7}{|c|}{$\begin{array}{l}\text { Variable Mean of Territory Management (X3) } \\
\end{array}$} & 3,79 \\
\hline
\end{tabular}

has been used, and distribution facilities and infrastructure promotion.

Table 6. Variable Description of Territory Management (X3)

\begin{tabular}{|c|c|c|c|c|}
\hline \multicolumn{3}{|c|}{ Indicators and Variables } & Mean & Loading Factor \\
\hline X34 infrastructure promotion & <--- & X3 territory management & 3,41 & $\mathbf{0 . 5 8 9}$ \\
\hline X33 Distribution channel activation & <--- & X3 territory management & 4,25 & 0.781 \\
\hline X32 Availability \& visibility product & $\begin{array}{ll}<-- \\
\end{array}$ & X3 territory management & 4,07 & 0.596 \\
\hline $\begin{array}{c}\text { X31 Equitable distribution of PTM } \\
\text { products }\end{array}$ & $<---$ & X3 territory management & 3,42 & 0.512 \\
\hline
\end{tabular}

Table 7. Factors loading ( $\lambda$ ) Variable of Territory Management (X3)

\section{The Variable of Competitive Advantage}

Competitive advantage (Y1), is at the heart of business performance in the face of competition between universities. Competitive advantage is basically grew from the value or benefits agency created for users of Muhammadiyah universities of the uniqueness of higher education operations, which are superior to the competitors for equivalent benefits or unique benefits exceed the price offered. Indicators of competitive advantage consists of Firm Specific Advantages, Advantages Specific Localization, Relationship Specific Advantages and Competitive Strenghts / Performance. 
Analysis of Competitive Advantage in the perspective of Resources Based View.

\begin{tabular}{|c|c|c|c|c|c|c|c|}
\hline \multirow{2}{*}{$\begin{array}{l}\text { Indicator } \\
\text { Variables }\end{array}$} & \multirow[t]{2}{*}{ Item } & \multicolumn{5}{|c|}{ Percent of Respondents (\%) } & \multirow[t]{2}{*}{ (Mean) } \\
\hline & & 1. & 2. & 3. & 4. & 5. & \\
\hline \multirow{4}{*}{$\begin{array}{l}\text { Firm Specific } \\
\text { Advantages } \\
(\text { Y1.1) }\end{array}$} & Y1.1.1 & 2,8 & 14,8 & 40,8 & 39,4 & 2,1 & 3,23 \\
\hline & Y1.1.2 & 0,7 & 9,2 & 31,0 & 54,9 & 4,2 & 3,53 \\
\hline & Y1.1.3 & 1,4 & 6,3 & 27,5 & 58,5 & 6,3 & 3,62 \\
\hline & \multicolumn{6}{|c|}{ Indicators mean Firm Specific Advantages (Y1.1) } & 3,46 \\
\hline \multirow{5}{*}{$\begin{array}{l}\text { Localization } \\
\text { Specific } \\
\text { Advantages } \\
(\text { Y1.2) }\end{array}$} & Y1.2.1 & 0,7 & 10,6 & 40,8 & 39,4 & 8,5 & 3,44 \\
\hline & Y1.2.2 & 0,7 & 8,5 & 41,5 & 37,3 & 12,0 & 3,51 \\
\hline & Y1.2.3 & 2,8 & 7,7 & 35,2 & 45,8 & 8,5 & 3,49 \\
\hline & Y1.2.4 & 1,4 & 3,5 & 29,6 & 55,6 & 9,9 & 3,69 \\
\hline & \multicolumn{6}{|c|}{ Indicators mean Localization Specific Advantages (Y1.2) } & $\mathbf{3 , 5 3}$ \\
\hline \multirow{5}{*}{$\begin{array}{l}\text { Relationship } \\
\text { Specific } \\
\text { Advantages, } \\
\text { ( Y1.3) }\end{array}$} & Y1.3.1 & 1,4 & 6,3 & 33,8 & 50,0 & 8,5 & 3,58 \\
\hline & Y1.3.2 & 0,7 & 7,7 & 37,3 & 48,6 & 5,6 & 3,51 \\
\hline & Y1.3.3 & 0,7 & 7,0 & 43,7 & 45,8 & 2,8 & 3,43 \\
\hline & Y1.3.4 & 0,7 & 6,3 & 55,6 & 28,2 & 9,2 & 3,39 \\
\hline & \multicolumn{6}{|c|}{ Indicators mean Relationship Specific Advantages (Y1.3) } & 3,48 \\
\hline \multirow{6}{*}{$\begin{array}{l}\text { Competitive } \\
\text { Strenghts } \\
(Y 1.4)\end{array}$} & Y1.4.1 & 0,7 & 6,3 & 47,2 & 38,7 & 7,0 & 3,45 \\
\hline & Y1.4.2 & 0,7 & 8,5 & 43,7 & 35,2 & 12,0 & 3,49 \\
\hline & Y1.4.3 & 1,4 & 6,3 & 55,6 & 33,8 & 2,8 & 3,30 \\
\hline & Y1.4.4 & 2,8 & 8,5 & 51,4 & 31,0 & 6,3 & 3,29 \\
\hline & \multicolumn{6}{|c|}{ Indicators mean Competitive Strenghts (Y1.4) } & $\mathbf{3 , 3 8}$ \\
\hline & \multicolumn{6}{|c|}{ Variable Mean of Competitive Advantage (Y1) } & 3,46 \\
\hline
\end{tabular}

Table 8. Variable Description of Competitive Advantage (Y1)

\begin{tabular}{|c|c|c|c|c|}
\hline \hline \multicolumn{6}{|c|}{ Indicator and Variable } & Mean & Loading Factor \\
\hline Y11 Firm Spesific Advan & $<---$ & Y1 Competitive advantage & $\mathbf{3 , 4 6}$ & $\mathbf{0 . 5 9 8}$ \\
\hline Y12 Localization Spesific & $<---$ & Y1 Competitive advantage & $\mathbf{3 , 5 3}$ & $\mathbf{0 . 6 1 4}$ \\
\hline Y13 Relationship Spesific & $<---$ & Y1 Competitive advantage & $\mathbf{3 , 4 8}$ & $\mathbf{0 . 5 6 3}$ \\
\hline Y14 Competitive Strength & $<---$ & Y1 Competitive advantage & $\mathbf{3 , 3 8}$ & $\mathbf{0 . 5 8 9}$ \\
\hline \hline
\end{tabular}

\begin{tabular}{|c|c|c|c|c|c|c|c|}
\hline \multirow{2}{*}{$\begin{array}{l}\text { Indicator } \\
\text { Variables }\end{array}$} & \multirow[t]{2}{*}{ Item } & \multicolumn{5}{|c|}{ Percent of Respondents (\%) } & \multirow[t]{2}{*}{ (Mean) } \\
\hline & & 1. & 2. & 3. & 4. & 5. & \\
\hline \multirow{5}{*}{$\begin{array}{l}\text { Strategic } \\
\text { Planning } \\
(Y 2.1)\end{array}$} & Y2.1.1 & 2,1 & 11,3 & 47,2 & 31,0 & 8,5 & 3,32 \\
\hline & $\mathrm{Y} 2.1 .2$ & 0,7 & 7,7 & 37,3 & 36,6 & 17,6 & 3,63 \\
\hline & Y2.1.3 & 2,1 & 8,5 & 29,6 & 35,9 & 23,9 & 3,71 \\
\hline & Y2.1.4 & 1,4 & 4,9 & 12,7 & 49,3 & 31,7 & 4,05 \\
\hline & \multicolumn{6}{|c|}{ The mean indicator of strategic planning (Y2.1) } & 3,68 \\
\hline \multirow{5}{*}{$\begin{array}{l}\text { Leadership } \\
\text { (Y2.2) }\end{array}$} & Y2.2.1 & 2,1 & 2,8 & 19,7 & 46,5 & 28,9 & 3,97 \\
\hline & $\mathrm{Y} 2.2 .2$ & 2,1 & 4,9 & 9,9 & 52,1 & 31,0 & 4,05 \\
\hline & Y2.2.3 & 2,1 & 4,2 & 8,5 & 43,7 & 41,5 & 4,18 \\
\hline & Y2.2.4 & 4,2 & 3,5 & 16,2 & 47,9 & 28,2 & 3,92 \\
\hline & \multicolumn{6}{|c|}{ The mean indicator of leadership (Y1.2) } & 4,03 \\
\hline \multirow{5}{*}{$\begin{array}{l}\text { Organizational } \\
\text { Performance } \\
\text { Result ( Y2.3) }\end{array}$} & Y2.3.1 & 3,5 & 4,2 & 21,8 & 50,0 & 20,4 & 3,79 \\
\hline & $\mathrm{Y} 2.3 .2$ & 1,4 & 7,0 & 12,0 & 47,2 & 32,4 & 4,02 \\
\hline & Y2.3.3 & 2,8 & 4,2 & 9,9 & 64,8 & 18,3 & 3,92 \\
\hline & Y2.3.4 & 2,1 & 8,5 & 10,6 & 64,1 & 14,8 & 3,81 \\
\hline & \multicolumn{6}{|c|}{ The mean indicator of organizational performance result (Y1.3) } & 3,89 \\
\hline \multirow{4}{*}{$\begin{array}{lr}\text { Faculty } & \text { and } \\
\text { Staff } & \text { Focus } \\
(\text { Y2.4) } & \end{array}$} & Y2.4.1 & 0 & 4,2 & 16,9 & 51,4 & 27,5 & 4,02 \\
\hline & Y2.4.2 & 1,4 & 4,9 & 13,4 & 38,0 & 42,3 & 4,15 \\
\hline & Y2.4.3 & 4,2 & 2,1 & 16,2 & 36,6 & 40,8 & 4,08 \\
\hline & \multicolumn{6}{|c|}{ The mean indicator of Faculty \& Staff Focus (Y2.4) } & 4,08 \\
\hline \multirow{5}{*}{$\begin{array}{l}\text { Educational } \\
\text { and Support } \\
\text { Process } \\
\text { Management } \\
(\text { Y2.5) }\end{array}$} & Y2.5.1 & 3,5 & 12,0 & 13,4 & 26,8 & 44,4 & 3,96 \\
\hline & Y2.5.2 & 0,7 & 13,4 & 16,2 & 24,6 & 45,1 & 4,00 \\
\hline & Y2.5.3 & 2,8 & 16,9 & 23,9 & 38,0 & 18,3 & 3,52 \\
\hline & Y2.5.4 & 6,3 & 14,8 & 33,8 & 31,7 & 13,4 & 3,31 \\
\hline & \multicolumn{6}{|c|}{$\begin{array}{l}\text { The mean indicator of Educational and Support Process Management } \\
(\text { Y2.5) }\end{array}$} & 3,69 \\
\hline \multirow{2}{*}{$\begin{array}{l}\text { Information } \\
\text { and Analysis }\end{array}$} & Y2.6.1 & 5,6 & 12,7 & 31,0 & 33,1 & 17,6 & 3,44 \\
\hline & Y2.6.2 & 3,5 & 9,9 & 25,4 & 44,4 & 16,9 & 3,61 \\
\hline
\end{tabular}


Analysis of Competitive Advantage in the perspective of Resources Based View.

\begin{tabular}{|c|c|c|c|c|c|c|c|}
\hline \multirow[t]{2}{*}{$(\mathrm{Y} 2.6)$} & Y2.6.3 & 2,1 & 12,7 & 28,9 & 41,5 & 14,8 & 3,54 \\
\hline & \multicolumn{6}{|c|}{ The mean indicator of Information and Analysis (Y2.6) } & 3,53 \\
\hline \multirow{4}{*}{$\begin{array}{l}\text { Customer and } \\
\text { Market Focus } \\
\text { (Y2.7) }\end{array}$} & Y2.7.1 & 3,5 & 9,9 & 23,9 & 43,7 & 19,0 & 3,65 \\
\hline & Y2.7.2 & 4,9 & 9,9 & 42,3 & 35,9 & 7,0 & 3,30 \\
\hline & Y2.7.3 & 2,1 & 14,1 & 34,5 & 38,0 & 11,3 & 3,42 \\
\hline & \multicolumn{6}{|c|}{ The mean indicator of Customer and Market Focus (Y2.7) } & $\mathbf{3 , 4 5}$ \\
\hline \multicolumn{7}{|c|}{ Variable Mean Organizational Performance (Y2) } & 3,76 \\
\hline
\end{tabular}

Table 9. Loading Factors ( $\lambda$ ) Competitive Advantage Variables (Y1)

Variable of Organizational Performance

Organizational Performance (Y2), is a series of work produced by the Organization of Muhammadiyah universities in the period with reference to the standards set. Organizational Performance Indicators in PTM is strategic planning, leadership, organizational performance result, faculty and staff focus, educational and support process management, information and analysis, and customer and market focus.

Table 10. Variable Description Organizational Performance (Y2)

\begin{tabular}{|c|c|c|c|c|}
\hline \hline \multicolumn{6}{|c|}{ Indicator and Variable } & Mean & Loading Factor \\
\hline Y21 Strategic Planing & $<---$ & Y2 Org.Performance & $\mathbf{3 , 6 8}$ & $\mathbf{0 . 3 4 6}$ \\
\hline Y22 Leadership & $<---$ & Y2 Org.Performance & $\mathbf{4 , 0 3}$ & $\mathbf{0 . 4 6 5}$ \\
\hline Y23 Organizational Perfor & $<---$ & Y2 Org.Performance & $\mathbf{3 , 8 9}$ & $\mathbf{0 . 6 0 0}$ \\
\hline Y24 Faculty \& Staff Focus & $<---$ & Y2 Org.Performance & $\mathbf{4 , 0 8}$ & $\mathbf{0 . 5 6 7}$ \\
\hline Y25 Educational \& Support & $<---$ & Y2 Org.Performance & $\mathbf{3 , 6 9}$ & $\mathbf{0 . 5 0 6}$ \\
\hline Y26 Information \& Analysis & $<---$ & Y2 Org.Performance & $\mathbf{3 , 5 3}$ & $\mathbf{0 . 5 6 7}$ \\
\hline Y27 Customer \& Market & $<---$ & Y2 Org.Performance & $\mathbf{3 , 4 5}$ & $\mathbf{0 . 4 9 9}$ \\
\hline \hline
\end{tabular}

Table 11. Factors loading ( $\lambda$ ) Variable Organizational Performance (Y2)

\begin{tabular}{|c|l|c|c|c|}
\hline \hline No & \multicolumn{1}{|c|}{ Latent Variable } & KMO & $\begin{array}{c}\text { P(Bartlet's } \\
\text { sphericity) }\end{array}$ & Categories \\
\hline 1 & Market Orientation $\left(\mathrm{X}_{1}\right)$ & 0,640 & 0,002 & Valid \\
\hline 2 & Competence HR $\left(\mathrm{X}_{2}\right)$ & 0,654 & 0,000 & Valid \\
\hline 3 & Territory Management $\left(\mathrm{X}_{3}\right)$ & 0,611 & 0,000 & Valid \\
\hline 4 & Competitive Advantage $\left(\mathrm{Y}_{1}\right)$ & 0,747 & 0,000 & Valid \\
\hline 5 & Organizational Performance $\left(\mathrm{Y}_{2}\right)$ & 0,679 & 0,000 & Valid \\
\hline \hline
\end{tabular}

Table 12. Summary of Test Validity Indicator

\begin{tabular}{|c|l|c|c|c|}
\hline \hline No & \multicolumn{1}{|c|}{ Latent Variables } & Cronbach's Alpha & $\mathrm{P}(\mathrm{F})$ & Categories \\
\hline 1 & Market Orientation $\left(\mathrm{X}_{1}\right)$ & 0,629 & 0,001 & Reliable \\
\hline 2 & Competence HR $\left(\mathrm{X}_{2}\right)$ & 0,655 & 0,000 & Reliable \\
\hline 3 & Territory Management $\left(\mathrm{X}_{3}\right)$ & 0,627 & 0,000 & Reliable \\
\hline 4 & Competitive Advantage $\left(\mathrm{Y}_{1}\right)$ & 0,774 & 0,000 & Reliable \\
\hline 5 & Organizational Performance $\left(\mathrm{Y}_{2}\right)$ & 0,641 & 0,005 & Reliable \\
\hline \hline
\end{tabular}

Table 13. Summary of Reliability Test Results

\section{Analysis of Structural Equation Modeling (SEM)}

At this stage it will be discussed on the suitability test of the model and the significance test causality. The test results with the program AMOS version 16 gives the results of SEM models as shown in Figure 2 below which shows the influence of market orientation, HR Competencies, and Territory Management for Competitive Advantage and Organizational Performance and Competitive Advantage on Organizational Performance in Higher Education Muhammadiyah in Indonesia.

a. Model of Conformity Test (Goodness of Fit Test)

Tests on the model SEM aims to look at the suitability of the model, the results of testing the suitability of the model in this study are presented in Table 14. based on the table it can be seen that of the eight criteria used to judge the worth / absence of a model has been fulfilled. 


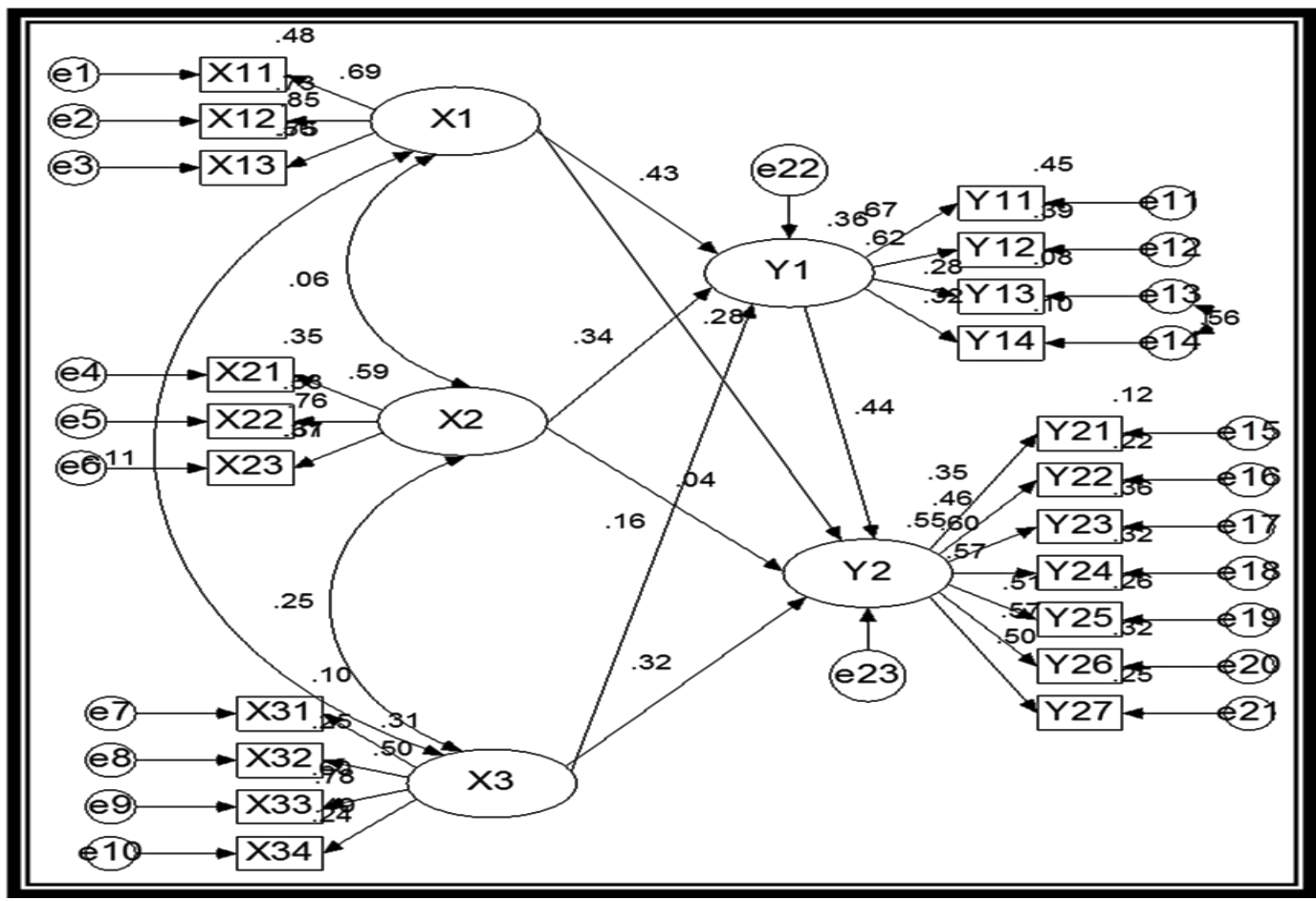

Figure 2. SEM analysis results

\begin{tabular}{|l|c|c|c|}
\hline \hline \multicolumn{1}{|c|}{ Criteria } & \multicolumn{1}{c|}{ Value Cut Off } & Test Results & Specification \\
\hline Chi Square & $\begin{array}{l}\text { Expected to be smaller than } \\
\text { the X2 on df }=178\end{array}$ & 181,390 & Good \\
\hline Sig. Probability & $\geq 0,05$ & 0,127 & Good \\
\hline RMSEA & $\leq 0,08$ & 0,071 & Good \\
\hline GFI & $\geq 0,90$ & 0,924 & Good \\
\hline AGFI & $\geq 0,90$ & 0,911 & Good \\
\hline CMIN/DF & $\geq 2$ atau 3 & 1,019 & Good \\
\hline TLI & $\geq 0,95$ & 0,957 & Good \\
\hline CFI & $\geq 0,95$ & 0,955 & \\
\hline \hline
\end{tabular}

Table 14. SEM of Conformity Index

So it can be stated that the model can be accepted, which means there is a match the model with the data.

\begin{tabular}{|c|c|c|c|c|c|c|}
\hline $\mathbf{H}$ & Hypothesis & Estimate & C.R. & $\mathbf{P}$ & Label & $\begin{array}{l}\text { decision on the } \\
\text { hypothesis }\end{array}$ \\
\hline H1 & $\begin{array}{c}\text { Market Orientation - } \\
\text { Competitive Advantage }\end{array}$ & 0,299 & 3,161 & 0,002 & Sig. & accepted \\
\hline H2 & $\begin{array}{c}\text { HR Competency - Competitive } \\
\text { Advantage }\end{array}$ & 0,338 & 2,516 & 0,012 & Sig. & accepted \\
\hline $\mathbf{H 3}$ & $\begin{array}{l}\text { Territory Management- } \\
\text { Competitive Advantage }\end{array}$ & 0,189 & 1,188 & 0,235 & Not Sig. & denied \\
\hline H4 & $\begin{array}{c}\text { Competitive Advantage - } \\
\text { Organizational Performance }\end{array}$ & 0,105 & 1,984 & 0,047 & Sig. & accepted \\
\hline H5 & $\begin{array}{c}\text { Market Orientation - } \\
\text { Organizational Performance }\end{array}$ & 0,197 & 2,057 & 0,040 & Sig. & accepted \\
\hline H6 & $\begin{array}{c}\text { HR Competencies - } \\
\text { Organizational Performance }\end{array}$ & 0,023 & 0,329 & 0,742 & Not Sig. & denied \\
\hline H7 & $\begin{array}{c}\text { Territory Management- } \\
\text { Organizational Performance }\end{array}$ & 0,233 & 2,056 & 0,040 & Sig. & accepted \\
\hline
\end{tabular}

Table 15. Hypothesis Test Results 


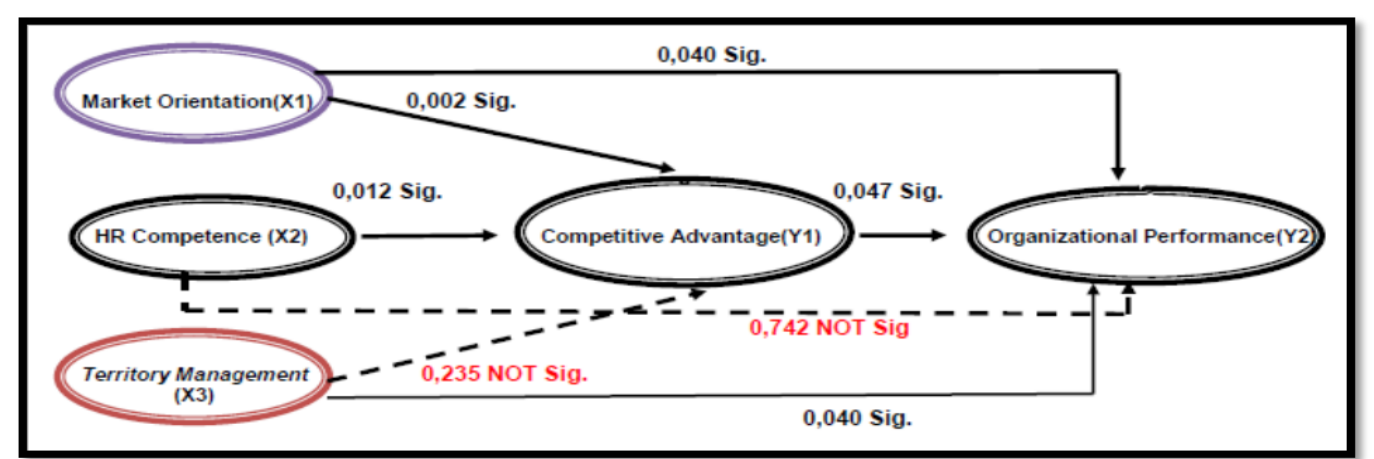

Figure 3. Path Diagram Testing Hypotheses

\begin{tabular}{|c|c|c|c|}
\hline \hline \multirow{2}{*}{ Direct Effect } & \multicolumn{3}{|c|}{ Endogenous Variables } \\
\cline { 2 - 4 } & & $\mathrm{Y}_{1}$ & $\mathrm{Y}_{2}$ \\
\hline \multirow{3}{*}{ Exogenous variables } & $\mathrm{X}_{1}$ & 0,428 & 0,282 \\
\cline { 2 - 4 } & $\mathrm{X}_{2}$ & 0,342 & 0,043 \\
\cline { 2 - 4 } & $\mathrm{X}_{3}$ & 0,164 & 0,322 \\
\cline { 2 - 4 } & $\mathrm{Y}_{1}$ & 0,000 & 0,440 \\
\hline \hline
\end{tabular}

Table 16. Direct Effect of Variables

\begin{tabular}{|c|c|c|c|}
\hline \hline \multirow{2}{*}{ Indirect Effect } & \multicolumn{3}{|c|}{ Endogenous Variables } \\
\cline { 2 - 4 } & & $\mathrm{Y}_{1}$ & $\mathrm{Y}_{2}$ \\
\hline \multirow{3}{*}{ Exogenous variables } & $\mathrm{X}_{1}$ & 0,000 & 0,188 \\
\cline { 2 - 4 } & $\mathrm{X}_{2}$ & 0,000 & 0,150 \\
\cline { 2 - 4 } & $\mathrm{X}_{3}$ & 0,000 & 0,072 \\
\cline { 2 - 4 } & $\mathrm{Y}_{1}$ & 0,000 & 0,000 \\
\hline
\end{tabular}

Table 17. Indirect Effect of Variable

\begin{tabular}{|c|c|c|c|}
\hline \hline \multirow{2}{*}{ Total Effect } & \multicolumn{3}{|c|}{ Endogenous Variables } \\
\cline { 2 - 4 } & & $\mathrm{Y}_{1}$ & $\mathrm{Y}_{2}$ \\
\hline \multirow{3}{*}{ Exogenous variables } & $\mathrm{X}_{1}$ & 0,428 & 0,471 \\
\cline { 2 - 4 } & $\mathrm{X}_{2}$ & 0,342 & 0,193 \\
\cline { 2 - 4 } & $\mathrm{X}_{3}$ & 0,164 & 0,395 \\
\cline { 2 - 4 } & $\mathrm{Y}_{1}$ & 0,000 & 0,440 \\
\hline \hline
\end{tabular}

Table 18. Total Effect of Variable

\section{Effect of Market Orientation on Competitive Advantage}

\section{Discussion}

The results showed Market Orientation factors have a significant influence on Competitive Advantage. So the hypothesis that increasing the degree of market orientation can enhance competitive advantage proven true or $\mathrm{H1}$ is accepted. The research findings indicate Market orientation has significant influence on the Competitive Advantage with emphasis on the orientation of its competitors through the implementation of the map of college competition, collecting competitor information, as well as share information about competitors in the unit and the internal functioning of colleges. Besides that it, the role of cross-functional coordination through regular coordination among leaders, leaders and employees, as well as regular coordination and leadership of the Lecturers as a supporting competitor orientation in the form of Competitive Advantage.

More specifically, this study is in line with the results of the study Mazaira et al., [119] and Ferdinand [120] noted the importance of the role of market orientation in building a company's competitive advantage. If the company has a corporate marketing strategy that is different from its competitors, the company will gain a competitive advantage. The results showed that the model relationship towards market orientation and competitive advantage is a significant positive. However, these results do not get the result that is consistent when compared to research Slater and Narver [121], Narver et al., [122], which examines the marketing of the product object, the relationship of market orientation toward competitive advantage not significant.

\section{HR Competency influence on Competitive Advantage}

The results showed HR Competency factors have a significant influence on Competitive Advantage. So the hypothesis that increasing the degree of HR competencies can improve competitive advantage $\mathrm{H} 2$ proven true or accepted. The findings showed an increase in knowledge of aspects of human resources for leaders, 
lecturers, and employees to get to work to establish expertise in Competitive Advantage. Besides, it can be supported by the award of achievement, dedication, loyalty, and honesty in order to ensure an increase in HR Competencies, Competitive Advantage that can be achieved by the College.

The results are consistent with the opinion of Mabey et al., [123], and Ellinger et al.,[124] that recognize the importance of human resource competencies, capabilities and skills as the company's primary source of competitive advantage. In line with research Khandekar and Sharma,[125] Developing a lot of workers who have the skill and ability in the field of high technology can be one of the main sources of competitive advantages. The results showed that the model of the relationship of human resource competencies for competitive advantage is positive and significant. However, the results of this study contrasts with the results of research Lengnick-Hall and Lengnick -Hall[126], and Wright et al.,[127], which states the relationship of human resource competencies competitive advantage is not significant, but should be in mediation by a factor of innovation.

\section{Effect of Territory Management for Competitive Advantage}

The results showed Territory Management factors have not a significant influence on Competitive Advantage. So the hypothesis that the increased degree of Territory Management can improve competitive advantage not truth or $\mathrm{H3}$ denied. The findings showed PTM aspects of product distribution services, availability of Faculty, Department, and Program Studies are needed society, promotion, and distribution channel activation services that have been used can not directly establish a Competitive Advantage.

The result is in line with the opinion of David Burgoyne et al.[128], which examines the relationship between Territory Management and Competitive Advantage, with a case study approach on a variety of companies in Canada, got the finding that when administered territory management and well developed, two of three (about 67\%) of the company marketing the region in general has the opportunity to grow and can be a source of competitive advantage for firms. With the conclusion, the influence of the Territory Management competitive advantage is not significant, unless moderated by variable sales productivity. But the results are not in line with the opinion of the research team from Agency Sales Magazine [129], and Allen [130], which states that the Territory Management significant impact on competitive advantage.

Effect of Market Orientation on Organizational Performance

The results showed that Market Orientation have significant influence on Organizational Performance. So the hypothesis that increasing the degree of market orientation can enhance organizational performance proven true or $\mathrm{H} 5$ is accepted. Th isresearch findings indicate Market orientation has significant influence on the performance organization with emphasis on the implementation knowing competitors-oriented through college competitive landscape, gathering competitor information, as well as share information about competitors in the unit and the internal functioning of the college. Besides, the role of cross-functional coordination through regular coordination among leaders, leaders and employees, as well as regular coordination and leadership of the Faculty, as a supporting competitor orientation in the form of Organizational Performance.

The result is in line with studies Jaworski \& Kohli [131], Slater \& Narver [132], Baker \& Sinkula [133], Castro et al.,[134]. Kirca et al.,[135] as well as Bhutia \& Jain [136] concluded that market orientation is a determinant of firm performance regardless of the external environment in which it operates. Also shows indicate that market orientation is significantly related to company performance. However, the results of this study differ with the findings Selnes et al.,[137] Pelham [138]. Han et al.,[139], Deshpande et al.,[140], and Harris [141] states that the market orientation but not significant positive effect on firm performance. However, in these studies revealed that the significant effect of market orientation on company performance, through innovation as an intervening variable.

Effect on HR Competence to Organizational Performance

The results showed HR Competency factors had no significant effect on Organizational Performance. So the hypothesis that increasing the degree of HR competencies can improve organizational performance is not proven true or $\mathrm{H} 6$ is rejected. The study findings suggest the implementation of aspects of human knowledge for leaders, lecturers, and employees to gain expertise in the work have not been able to establish Organizational Performance. Besides, the factors supporting an award of achievement, dedication, loyalty, and honesty in order to ensure an increase in HR Competency, and also aspects of leadership ability, lecturers, and employees in carrying out the duties and functions have not been a significant effect on the formation of Organizational Performance in Higher Education of Muhammadiyah.

The result is in line with the opinion of Armstrong [142], and Esra [143], which states that the relationship with the HR competencies organizational performance, must be moderated by an increase in the quality of products (goods \& services) and human resource productivity improvement. So that the direct effect of HR competencies with organizational performance, is positive was not in significant. But the results are not consistent with Huselid study, [144], Delaney and Huselid, [145]; Huselid, Jackson and Schuler, [146] in which the results of the survey on manufacturing firms in the United States prove that the index of High Performance 
Work system correlated with HRM systems. HR performance is highly correlated with the performance of the company and called the system of human resource management practices in the organization.

Effect of Territory Management on Organizational Performance

The results showed Territory Management factors have a significant influence on Organizational Performance. So the hypothesis that the increased degree of Territory Management can improve organizational performance proven true or acceptable H7. The findings of the study explains the importance of activating Alumni Network, Network Professional, Student Organizations, as well as synergies with Muhammadiyah Persyarikatan on many levels, is a major factor in forming the significance Organizational Performance. Besides, it is supported by the availability of Faculty, Department, Program, and Concentration scientific community needs. The result is in line with studies David Burgoyne; Terry Deutscher; Stephen Ash [147], Agency Sales Magazine [148]; Allen, [149] concluded that the Territory Management that will either be able to assist the company in to success.

Effect of Competitive Advantage on Organizational Performance

The results showed Competitive Advantage factors have a significant influence on Organizational Performance. So the hypothesis that increasing the degree of competitive advantage can improve organizational performance proven true or $\mathrm{H} 4$ accepted. The findings of the study explains the importance of pursuing uniqueness Interior Design, unique panoramic surroundings, unique infrastructure, and unique access to transportation to ensure the establishment of Organizational Performance. In addition, it is also important to seek the uniqueness of human resource management, asset management, and institutional management. Naturally, too, with no override aspects of academic achievement and non-academic as well as building a network of bureaucracy, academic networks, social networks and religious culture, all that can ensure the creation of the expected performance for the organization Muhammadiyah Universities.

The result is in line with studies Strandskov [150] measures the company's competitive advantage by using four variables, namely Firm Specific Advantages, Advantages Specific Localization, Relationship Specific Advantages and Competitive Strenghts / Performance. Strandskov The results found that competitive advantage in the form of Firm Specific Advantages and Relationship Specific Advantages over effect on the success of organizational performance. Competitive advantage (competitive advantage) allows enterprises to obtain superior performance on a period of time [151].

Theoretical contributions

Reinforce the concept of Barney [152] who pointed out that the physical resources (eg, physical technology, buildings and equipment, geographic location, and means of learning) are rarely capable of generating sustainable competitive advantage because this resource is relatively easy to follow and can move anywhere. In this case evidenced from Territory Management implementation in PTM.

Developing the concept of Lindquist \& Tallman, [153]. Of sorting the types of internal resource-based Resources Based View, which seems most likely to be the source of sustainable advantage is the real "invisible assets" or "core competence" of human capital and organizational skills that can be specific to the company. Manifestation of the concept, the research approach of the market orientation and HR Competency, through enrichment indicator objectively at Muhammadiyah University.

\section{Practical Contribution}

Provide conceptual guide for The Leader of Muhammadiyah universities, the importance of efforts to realize a competitive advantage through the Firm Specific Advantages indicator on the uniqueness of human resource management sector, assets, and institutional. Specific Localization Advantage indicator on the uniqueness of the facilities and infrastructure sector learning process. Relationship Specific Advantages indicator with a network of political / bureaucratic, academic networks, social, and cultural. Competitive Strenghts with a unique indicator of achievement through academic and non-academic.

Emphasized the importance of implementation of market orientation as a culture to the academic community in seeking PTM customer value for students and the community, in order competitive advantage can be achieved so that the performance of the organization can be improved. Further explaining the strategic value of HR Competency as a core capability in forming the organization's Competitive Advantage in Higher Education of Muhammadiyah. As well as a self-introspection, given the implementation of good HR Competency at Muhammadiyah universities have not been able to significantly shape Organizational Performance.

\section{limitations of Research}

In the measurement of market orientation, should ideally measured data taken from three parties, namely the internal PTM, PTM competitor, and PTM service users. However, this study only measured from the internal side of the PTM, in this case the head of each in 155 PTM as respondents. In PTM organizational performance measurement, more perfect if PTM approach service users (students and community) as well as 
through external assessment team PTM (BAN-PT, or some sort of independent assessment institution). However PTM organizational performance in this study is limited to the perception of leadership on organizational performance in PTM for their agencies.

\section{Conclusion}

Competitive Advantage in Higher Education of Muhammadiyah is the main topic in this study, is an important and a good thing in the perception of leadership PTM in Indonesia, this indicates that the existing PTM awareness among leaders of the importance of seeking a competitive advantage in the face of competition between universities. This awareness can be seen as good indicators Advantages Specific Localization, specific aspects of excellence that meets the prerequisites Value, Rareness, Inimitability, as well as the non-uniqueness in the embodiment Substitutable Interior Design of buildings and building models are used, the uniqueness of the Panorama the environment in which PTM domiciled and conducting process activities teaching and learning, uniqueness operational infrastructure of a university, and the uniqueness of transportation access, in a sense can be easily reached from all directions with various types of public transportation used by the community, which is characteristic of Muhammadiyah universities in Indonesia. It is also supported by a good indicator of Firm Specific Advantages, aspects of the management and operational capabilities in running universities to meet the criteria Value, Rareness, Inimitability, and Non-Uniqueness Substitutable through the implementation of human resource management, asset management uniqueness, and uniqueness of institutional management. All that has been proved that the Competitive Advantage in Higher Education Muhammadiyah significant effect on Organizational Performance. PTM's just need to improve aspects of Relationship Specific Network Advantage through strengthening Politics / Bureaucracy, Network Academic, Social Networking Sites, and Cultural Network, and Competitive Strenghts. through the strengthening of academic achievement and non-academic achievements at Muhammadiyah University.

Competitive advantage in Muhammadiyah universities strongly shaped by market orientation is a culture of leadership, lecturers, and employees who prioritize customer value for service users in Muhammadiyah universities and produce "superior performance" for the organization Muhammadiyah universities, especially in environments competing. This can be seen from the good factors Market Orientation through the importance of knowing the competitive landscape universities, collecting data and information on competitors, as well as share information about competitors in other functions in Muhammadiyah University. The next support is the need for coordination between the routinely performed Leadership, Leadership and lecturers, as well as leaders and employees. It's just that still needs to be improved is the customer orientation indicator in monitoring the extent of PTM through the commitment of leaders, lecturers and staff to the customers (students). The development of competitive strategy is based on understanding the needs of service users universities, and an understanding of how aspects of management can create customer value.

HR Competency factors, empirically in Muhammadiyah universities is an important issue in the formation of competitive advantage, particularly through the implementation indicator personal attributes (personal attributs) were able to distinguish someone who perform and not perform, including achievement, dedication, and the loyalty of human resources in The Higher Education of Muhammadiyah. This is reasonable considering HR in PTM based on Persyarikatan as a cadre organization, where personal attributes to be "selling" Muhammadiyah in running charitable efforts, particularly in the form of business charitable Institutions. So that personal attributes can ensure the long-term management firm indicator spesific advantages in establishing a sustainable Competitive Advantage of PTM in Indonesia. However, there are research findings that need to be observed, that good HR Competency in Muhammadiyah universities have not been able to significantly shape Organizational Performance, which can be used as a rationale answer is: if the aspect of "hardware" HR Competency is good, meaning that need to be reviewed is the aspect of "Software "of human resources work in the PTM, among others, the implementation of shared values espoused, or the noble values of Islamization and value of" Ke-Muhammadiyahan" that needs to be revisited. Referring to the results of decision Tanfids Muhammadiyah Congress A 46th Century [154], it can happen when the capability aspects are less encouraged by the lofty values Ke-Muhammadiyahan, an absolute must-have for any personnel who take part in Charity Effort Muhammadiyah, including the personal Leadership, Faculty, and Staff in Universities of Muhammadiyah.

From the perspective of Territory Management, it is empirically have not been able to support the formation of Competitive Advantage PTM, given the equal implementation "Catur dharma" benefits of Muhammadiyah universities for people in the area of marketing that can be reached, the availability of educational services and the choice of courses required by the public, use of media Advertising, Personal selling, sales promotion and publicity on a higher education PTM services offered in the target area have not been cultivate uniqueness / something unique to meet the criteria Value, Rareness, Inimitability, and NonSubstitutable through strengthening the quality indicators that can differentiate and establish the advantage over other universities ; within the meaning of territory Management conducted indicators are relatively similar (have 
not been appeared uniqueness) than any other competitor universities in each region of PTM. But on the other hand Territory Management status indicator important and significant in the formation of organizational performance in PTM.

Competitive advantage in PTM is a major factor in supporting organizational performance, followed by factor of Market Orientation and Territory Management implementation. Organizational Performance Indicator strongest formation demonstrates the importance of improving the quality of new students as well as the quality of graduates, plus a number of aspects of the addition of new students and the number of graduates. Further still important to seek financing mechanisms, infrastructure management and information systems management mechanism effectively and efficiently, in accordance with the characteristics of Muhammadiyah universities respectively.

\section{Suggestions}

Based on the analysis and discussion, it can put forward some suggestions that can be considered good for PTM management leaders, researchers, academics, and practitioners as follows:

For Muhammadiyah universities, it is important to increase the intensity and routinely conduct training, cadre courses, lectures and various media representative to instill the values of Islamization, and the values of KeMuhammadiyahan for all Leaders, Faculty, and Staff in Universities of Muhammadiyah, because according to the research results, as well as the professional aspects of human resource capabilities and competencies that either have not been able to significantly shape the expected Organizational Performance. Decisions based on the results Tanfidz Muhammadiyah Congress A Century[155] it can happen when the capability aspects are less encouraged by the lofty values Ke-Muhammadiyahan, an absolute must-have for any personnel who take part in Charity Effort Muhammadiyah, which includes personal leadership, Lecturer , and Employees at Muhammadiyah University.

Furthermore and business leaders need to improve aspects PTM Relationship Specific Advantage through strengthening partnership and sharing program in Network Politics / Government bureaucracy at various levels in the PTM, respectively, with enrichment Network Academic Institutions and Scientific Institutions both within and outside the country, devotion cooperation community with Social Networking Sites, as well as preservation of cultural heritage and national areas involving Culture network in society, and Competitive Strenghts. through the strengthening of academic achievement and non-academic achievements at Muhammadiyah University.

Lastly, the PTM must increase synergy with Muhammadiyah Persyarikatan on many levels, it is important in supporting the long-term performance of PTM. On the other hand the creativity in communicating the services of higher education needs to be improved (Promotional Mix). Further considering the needs of higher education services to the community is very diverse, it is advisable to be able to open the course or current concentration of knowledge needed by the people, so the Competitive Advantage can be achieved. Hopefully.

For the researchers, future studies are needed comprehensive review of the extent and aspect Values and Ethos The Muhammadiyah can affect Organizational Performance in Higher Education in Charity Effort Muhammadiyah or other Persyarikatan, and how aspects of the share value, in this case the value and ethos to Muhammadiyahan can be implemented to get a Competitive Advantage for Higher Education Muhammadiyah.

\section{REFERENCES}

[1] Warnars, Spits (2010):"Tata Kelola Data Base Perguruan Tinggi yang optimal dengan Data Warehouse”. TELKOMNIKA ISSN: 1693-6930. Vol. 8, No. 1, April 2010:25 - 34

[2] Kotler, P. (2010). Marketing management, 19th edn, Prentice Hall, Upper Saddle River, N.J.

[3] Johnson, G., Scholes, K. (2003). "What is strategy", available from http://www.tutor2u.net/business/ strategy /what_is_strategy.htm [accessed at Januari 12, 2012].

[4] Thompson, A.A., Strickland III, A.J. (2003). Strategic management: Concepts and cases, 13rd edn, New York, Mc Graw-Hill Companies.Inc.

[5] Porter, Michael (1980):"Competitive Strategy: Techniques for Analyzing Industries and Competitors." Qfinance Jurnal

[6] Teece, D.J. (1984). "Economic analysis \& strategic management”, California Management Review, 26, (3), Spring, pp. 87-110.

[7] Barney, Jay B(1991):'Firm Resources and Sustained Competitive Advantage", Journal of Management, 17, 99-120

[8] Hitt, M.A., Ireland, R.D., Camp, S.M., Sexton, D.L.(2001). "Guest editors' introduction to the special issue strategic entrepreneurship: Entrepeneurial strategies for wealth creation”, Strategic Management Journal, 22. pp. 479 - 491.

[9] Aaker, D. A. (1989), "Managing Assets and Skills: The Key to a Sustainable Competitive Advantage", California Management Review, 31(Winter), pp. 91 - 106.

[10] Barney, J.B., (1986a).’Strategic Factor Markets: Expectations, Luck and Business Strategy", Management Science, Vol.32, pp.1231-1241.

[12] Barney, J. B. (1995), "Looking inside for competitive advantage", Academy of Management Review, 19(4), pp. 49-61.

[13] Oliver, C. (1997), "Sustainable Competitive Advantage: Combining Institutional and Resource-Based Views", Strategic Management Journal, 18(9), pp. $697-713$.

[16] Cervera, A., Molla, A., \& Sanchez, M. (2001).:"Antecedents and consequences of market orientation in public organizations." European Journal of Marketing, 35 (11/12), 1259-1286

[17] Kotler, P. \& Levy, S. (1969).” Broadening the Concept of Marketing.” Journal of Marketing, 33 (1), 10-15.

www.iosrjournals.org $\quad 46 \mid$ Page


[18] Yeni, Yulia Hendri. (2007 ).:" Orientasi Pasar dan Kinerja Institusi Pendidikan di Indonesia: Kajian Empiris untuk Meningkatkan Keunggulan Bersaing." Fakultas Ekonomi Universitas Andalas Padang.

[20] Maydeu-Olivares, A. \& Lado, N. (2003).:"Market orientation and business economic performance: A mediated model." International Journal of Service Industry Management, 14 (3/4), 284-309.

[21] Wright PM, Mc.Mahan GC, McCormick B, Sherman WS (1998)."Strategy, core competence, and HR involvement as determinants of HR effectiveness and refinery performance". Human. Resources. Management..37(1): 17-29.

[22] Lengnick-Hall, C. A. \& Lengnick-Hall, M. L. (1990). "Interactive human resource management and strategic planning”. New York: Quorum Books.

[23] Brewster, C; Dowling, P; Grobler, P; Holland, P dan Warnich, S.(2000)." Contemporary Issues in HRM: Gaining a Competitive Advantage". Oxford Uniersity Press: Southern Africa.

[24] Burgoyne, D; Deutscher, T dan Ash, S. 1980. "Sales territory management: key to sales force productivity". Business Quarterly, Autumn 45:2.

[25] Agency Sales Magazine (1991) :"Territory Management for the Growing Sales Agency". HighBeam Business is operated by Cengage Learning. () Copyright 2011. All rights reserved (accessed at Nopember, 30 2011).

[26] Allen, Daryl, 2005. "Relationship selling is key to territory management success". Selling, 10691952, Apr.

[27] Castro, C.B., Armario, E.M., Sanchez del Rio, M.E., (2005), "Consequences of market orientation for customers and employees." European Journal of Marketing," 39 (5), 646-75.

[28] Kirca, A.H., Jayachandran, S. \& Bearden, W.O. (2005)."Market orientation: A meta-analytic review and assessment of its antecedents and impact on performance." Journal of Marketing, 69: 24-41.

[29] Jain, Sanjay, K. and Bhutia, Manju. (2007)."Market Orientation and Business Performance: The case of Indian Manufacturing Firm”. The Journal of Busines Perspective. Vol. 11. No.1 (January-March). pp.15-33.

[30] Jaworski, BJ dan Kohli, AK (1993), "Market Orientation: Antecedents and Consequences", Journal of Marketing, Vol. 57, p. 5370 .

[31] Selnes, F., Jaworski, B.J. and Kohli, A.K. (1996), "Market orientation in United States and Scandinavian companies. A crosscultural study", Scandinavian Journal of Management, Vol. 12 No. 2, pp. 139-57.

[32] Pelham, Alfred M (1997) "Market orientation and performance: the moderating effects of product and customer differentiation", Journal of Business \& Industrial Marketing, Vol. 12 Iss: 5, pp.276 - 296

[33] Deshpande, R., Farley, J. U., \& Webster, F. E. Jr. (2000). "Triad lessons: Generalizing results on high performance firms in five business-to-business markets". International Journal of Research in Marketing, 17(4), 353-362.

[34] Harris L C (2002). "Market orientation and performance: Objective and subjective empirical evidence from UK companies". $J$. Manag. Stud., 38 (1):17-43.

[36] Penrose, E. T. (1959). The Theory of the Growth of the Firm. New York: John Wiley.

[37] Wernerfelt, B., (1984). “A Resource-Based View of the Firm”, Strategic Management Journal, Vol.5, pp.171-180.

[38] Rumelt, D.P., (1984), Towards a Strategic Theory of the Firm. Alternative theories of the firm; 2002, (2) pp. 286-300, Elgar Reference Collection. International Library of Critical Writings in Economics, vol. 154. Cheltenham, U.K. and Northampton, Mass.: Elgar; distributed by American International Distribution Corporation, Williston, Vt.

[39] Mahoney, J.T. and Pandian, J.R. (1992), "The resource-based view within the conversation of strategic management", Strategic Management Journal, Vol. 13 No. 5, pp. 363-380.

[40] Barney, J.B. and Arikan, A.M. (2001), "The resource-based view: origins and implications", in Hitt, M.A., Freeman, R.E. and Harrison, J.S. (Eds), The Blackwell Handbook of Strategic Management, Blackwell, Oxford, UK.

[41] Zubac, Angelina., Hubbard, Graham.,and Johnson, Lester W.,(2010):”The RBV and value creation: a managerial perspective". European Business Review. Vol. 22 No. 5,. pp. 515-538 @ Emerald Group Publishing Limited.

[44] Porter, Michael E.(1985) :"Competitive Advantage: Creating and Sustaining Superior Performance”. New York:The Free Press, 1985. Presents a traditional view of strategic thinking.

[45] Hoskisson, R.E., Hitt, M.A., Wan, W.P. and Yiu, D. (1999), "Theory and research in strategic management: swings of a pendulum", Journal of Management, Vol. 25 No. 3, pp. 417-457.

[47] Conner, K.R. (1991), "A historical comparison of resource-based theory and five schools of thought within industrial organization economics: do we have a new theory of the firm?", Journal of Management, Vol. 17 No. 1, pp. 121-154.

[48] Teece, D.T., G. Pisano and A. Shuen, (1997).”Dynamic Capability and Strategic Management”, Strategic Management Journal, Vol.18, No.7, pp.509-533.

[49] Lockett, A. and Thompson, S. (2001), "The resource-based view and economics", Journal of Management, Vol. 27, pp. 723-754.

[52] Wernerfelt, B. (1995), "The resource-based view of the firm: ten years after", Strategic Management Journal, Vol. 16 No. 3, pp. 171-4.

[54] Mahoney, J.T. (2005), Economic Foundations of Strategy, Sage, Thousand Oaks, CA.

[57] Dierickx, I. and K. Cool, (1989)."Asset Stock Accumulation and Sustainability of Competitive Advantage, "Management Science, Vol.35, pp.88-108.

[60] Barney, J.B. (2001b), "Resource-based theories of competitive advantage: a ten year retrospective on the resource-based view", Journal of Management, Vol. 27, pp. 643-650.

[63] Prescott, E. C., \& Visscher, M. (1980), "Organization Capital", Journal of Political Economy, 88(3), pp. 446 - 461.

[66] Oliver, C. (1997), "Sustainable Competitive Advantage: Combining Institutional and Resource-Based Views", Strategic Management Journal, 18(9), pp. 697 - 713.

[67] Peteraf, M.A., (1993). "The Cornerstones of Competitive Advantage: a Resource-Based View", Strategic Management Journal, Vol.14, pp.179-191.

[68] Hearn, G., Glose A., Smith, B dan Southey, G (1996), "Defining Generic Professional Competencies in Australia: Towards a Framework for Professional Development", Asia Pacific Journal of Human Resource, Vol. 34 No.1, p. 44-62.

[69] Hunt, J. B., \& Wallace, J. (1997), "A competency-based approach to assessing managerial performance in Australian context", Asia Pacific Journal of Human Resources, 35(2), pp. 52 - 66.

[70] Lado, A. A., Boyd, N. G., \& Wright, P. (1992), "A competency based model of sustainable competitive advantage: toward a conceptual integration", Journal of Management, 18(1), pp. 77 - 91.

[71] Bogaert, I., Martens, R., \& Cauwenbergh, A. V. (1994), "Strategy as a Situational Puzzle: The Fit of Components", . Baffins Lane, Chichester, England: John Wiley \& Sons Ltd.

[72] Grant, R.M., (1991). “The Resource-Based Theory of Competitive Advantage: Implications for Strategy Formulation”, California Management Review, spring, pp.114-135. 
[73] Hart, S. L., \& Banbury, C. (1994), "How strategy-making processes can make a difference", Strategic Management Journal, 15, pp. $251-269$.

[74] Oliver, C. (1997), "Sustainable Competitive Advantage: Combining Institutional and Resource-Based Views", Strategic Management Journal, 18(9), pp. 697 - 713.

[75] Chaharbagi, Kazem., and Lynch, Richard.,(1999):"Sustainable Competitive Advantage: Towards a dynamic Resource-Based Strategy". Management Decesion. 37/1. P 45-50 @ MCB University Press (ISSN 0255-1747).

[76] Song, M., Droge, C., Hanvanich, S., and Calantone, R.,(2005):"Marketing and Technology resource complementary: an analysis of their interaction effect in two environmental context". Strategic Management Journal, Vol. 26, pp.259-276.

[77] Morgan, Neil A., Kaleka, Anna., and Katsikeas, Constantine S.,(2004):"Antecedents of Export Venture Performance: A Theoretical Model and Empirical Assessment". Journal of Marketing, Vol. 68. PP 90-108.

[78] Finney, R., Campell, N., and Powell, C.,(2005):"Strategic and Resources: Pathways to Success?". Journal of Business Research, Vol. 58, pp1721-1729.

[82] Strandskov, J. (2006).:"Sources of Competitive Advantages and Business Performance." Journal of Business Economics and Management, 7(3), 119-129.

[84] Khandekar,A dan Sharma,A. (2005):"Managing human resource capabilities for sustainable competitive advantage ,An empirical analysis from Indian global organisations.” Education+Training, 47(8/9), 628-639.

[85] Slater, SF dan Narver, JC (1995), "Market Orientation and the Learning Organization", Journal of Marketing, Vol. 59, p. 63-74.

[86] Fahy,John (2000) "The resource-based view of the firm: some stumbling-blocks on the road to understanding sustainable competitive advantage", Journal of European Industrial Training, Vol. 24 Iss: 2/3/4, pp.94 - 104.

[87] Mazaira, Andrés. E. González, Ruth Avendaño, (2003) "The role of market orientation on company performance through the development of sustainable competitive advantage: the Inditex-Zara case", Marketing Intelligence \& Planning, Vol. 21 Iss: 4, pp. $220-229$

[89] Narver, J. C., Slater, S. F and B. Tietje (1998), “Creating a Market Orientation,” Journal of Market-Focused Management, 3 (2), 241-255.

[90] Mabey, C; Salaman, G dan Storey, J. (1998)." Human Resource Management: A Strategic Introduction.” Blackwell Publishers. Boston MA.

[91] Ellinger, A; Yang, B; dan Howton, S. (2002). "The relationship between the learning organization concept and firm's financial performance: an empirical assessment". Human Resource Development Quarterly, Vol. 13 No. 1.

[92] Wright PM, Mc.Mahan GC, McCormick B, Sherman WS (1998)."Strategy, core competence, and HR involvement as determinants of HR effectiveness and refinery performance". Human. Resources. Management.,37(1): 17-29.

[93] Brewster, C; Dowling, P; Grobler, P; Holland, P dan Warnich, S.(2000).” Contemporary Issues in HRM: Gaining a Competitive Advantage". Oxford Uniersity Press: Southern Africa.

[96] Baker, William E., James M. Sinkula, (1999), "The Synergistic Effect of Market Orientation and Learning Orientation on Organizational Performance", Journal of the Academy of Marketing Science, p.411-427.

[97] Han, J.K., Kim, N., Srivastava, R., (1998).”Market orientation and organizational performance": Is innovation a missing link? Journal of Marketing 62 (4), 30-45.

[100] Weatherley, L.A. (2003)."The Value of People:The Challenges and Opportunities of Human Capital Measurement and Reporting." Research Quarterly. Society for Human Resource Management.

[101] Greer, C.R. (2001) "Strategic Human Resource Management: A General Managerial Approach", 2nd edn. Englewood Cliffs, NJ: Prentice Hall.

[102] Harris, L. C. and Ogbonna, E., (2001),"Strategic human resource management, market orientation, and organizational performance," Journal of Business Research 51, 157-166

[103] Galbraith, J. and D. Nathanson. (1978)." Strategy Implementation: The Role of Structure and Process". St. Paul, MN: West Publishing.

[104] Baird, L. and I. Meshoulam (1988) 'Managing Two Fits of Strategic Human Resource Management', Academy of Management Review 13(1): 116-28.

[105] Huselid, M.A. (1995), "The Impact of Human Resource Management on Turnover, Productivity and Corporate Financial Performance", Academy of Management Journal, 38/3, 635 - 672.

[106] Delaney, J.i. and Huselid, Mark, (1996)."The impact of HRM practices on perception of organizational performance," Academy of Management Journal, Vol 39 (4), Boston.

[107] Huselid ,Mark A., Jackson ,Susan E. and Schuler, Randall S.(1997).” Technical and Strategic Human Resource Management Effectiveness as Determinants of Firm Performance". The Academy of Management Journal @ 1997Vol.40 No.1 Page 171-188

[108] Seth, A., \& Thomas, H. (1994), "Theories of the Firm: Implications for Strategy Research", Journal of Management Studies, 31(2, March), pp. $165-191$.

[109] Aaker, D. A. (1989), "Managing Assets and Skills: The Key to a Sustainable Competitive Advantage", California Management Review, 31(Winter), pp. 91 - 106.

[110] Amit, R. and P.J.H. Schoemaker, (1993). "Strategic Assets and Organizational Rent", Strategic Management Journal, Vol.14, pp.33-46.

[111] Bharadwaj, SG., Varadarajan, PR dan Fahy, J (1993), "Sustainable Competitive Advantage in Service Industries: A Conceptual Model and Research Proposition”, Journal of Marketing, Vol. 57, p. 83-100.

[112] Grant, R.M., (1991). "The Resource-Based Theory of Competitive Advantage: Implications for Strategy Formulation”, California Management Review, spring, pp.114-135.

[113] Hall, R. (1994), "A Framework for Identifying the Intangible Sources of Sustainable Competitive Advantage", In G.Hamel \& A. Heene (Eds.), Competence-Based Competition, pp. 149-169, Baffins Lane, Chichester, England: John Willey \& Sons Ltd.

[114] Lado, A. A., Boyd, N. G., \& Wright, P. (1992), "A competency based model of sustainable competitive advantage: toward a conceptual integration", Journal of Management, 18(1), pp. 77 - 91.

[115] Oliver, C. (1997), "Sustainable Competitive Advantage: Combining Institutional and Resource-Based Views", Strategic Management Journal, 18(9), pp. 697 - 713.

[117] Creswell, John W. (2002).” Desain Penelitian.”(terjemahan) Jakarta: KIK Press.

[118] Hair, J. Black, W. Babin, B. \& Anderson, R.,(2006)."Multivariate Data Analysis: a Global Perspective." 7th ed. Pearson: Prentice Hall.

[119] Mazaira, Andrés. E. González, Ruth Avendaño, (2003) "The role of market orientation on company performance through the development of sustainable competitive advantage: the Inditex-Zara case", Marketing Intelligence \& Planning, Vol. 21 Iss: 4 , pp. $220-229$ 
[120] Ferdinand, Augusty (2003):" Sustainable Competitive Advantage: Sebuah Eksplorasi Model Konseptual" Research Paper Series.Badan Penerbit Universitas Diponegoro Semarang.

[123] Mabey, C; Salaman, G dan Storey, J. (1998)." Human Resource Management: A Strategic Introduction." Blackwell Publishers. Boston MA.

[124] Ellinger, A; Yang, B; dan Howton, S. (2002). "The relationship between the learning organization concept and firm's financial performance: an empirical assessment". Human Resource Development Quarterly, Vol. 13 No. 1.

[142] Armstrong, Michael, (2008). "Strategic Human Resource Management: A Guide to Action", 4th Edition, Kogan Page, London.

[143] Esra, Nemli Caliskan (2010).” The Impact of Strategic Human Resource Management on Organizational Performance”. Journal of Naval Science and Engineering 2010, Vol. 6 , No.2, pp. 100-116.

[146] Huselid, M.A., Jackson, S.E. and Schuler, R.S. (1997), "Technical and Strategic Human Resource Management Effectiveness as Determinants of Firm Performance", Academy of Management Journal, 40/1, 171 - 188.

[151] Pitts, R. A. and D. Lei. (2003)."Strategic Management: Building and Sustaining Competitive Advantage”, Ohio: Thompson Learning.

[153] Lindquist, F. K., \& Tallman, S. (1997), "Resource-Based Strategy and Competitive Advantage Among Multinationals", In H. Vernon-Wortzel \& L. H. Wortzel (Eds.) 149 - 167, : John Wiley \& Sons, Inc.

[154] Tanfidz Keputusan Muktamar Satu Abad Muhammadiyah, (Muktamar Muhammadiyah ke 46), Yogyakarta, 20-25 Rajab 1431 H / 3-8 Juli 2010 M. Diterbitkan oleh Pimpinan Pusat Muhammadiyah, September 2010. 